\title{
The Design of Maternal Health Status Report System to Decrease Maternal Mortality in Jember Regency
}

\author{
Atma Deharja ${ }^{1, *}$ Maya Weka Santi ${ }^{2}$, Muhammad Yunus $^{3}$, Ervina Rachmawati ${ }^{4}$ \\ 1,2,3,4 Department of Health, Politeknik Negeri Jember, Indonesia \\ "Corresponding author. Email: atma_deharja@polije.ac.id
}

\begin{abstract}
Jember is the regency with the highest Maternal Mortality Rate (MMR) in East Java. In 2019, MMR of Jember Regency was the 5th highest rank with 133.4/100,000 KH. Therefore, efforts are needed to reduce maternal mortality in Jember Regency. The purpose of this study was to create a system for recording pregnant women as an effort to reduce maternal mortality in Jember Regency. This type of research is research and development research with SDLC method. The results of this study are an application of the maternal high-risk factor database of Jember Regency. Database applications allow you to integrate all your data and information properly, improving the quality of service and making it easier to store and access your data. This study concludes that the system produces rapid and accurate information to help with surgery and decision-making to reduce Jember's maternal mortality.
\end{abstract}

Keywords: Maternal Mortality, Information System, SDLC

\section{INTRODUCTION}

Jember Regency is one of the Morbidity and Maternal Rate (MMR) in East Java. In 2018, the MMR in Jember Regency was ranked $10^{\text {th }}$ with $114 / 100.000$ live births [1] and 133.4/100.000 live births in 2019. It means that reducing the MMR to $87.73 / 100.000$ live births has not been achieved [2].

The increase in maternal health services, which is not accompanied by an improvement in the MMR, indicates that the quality of maternal services is not yet optimal. For this reason, synergies and a robust information system must be built at the Primary Healthcare to carry out early detection of causes of maternal death and intervene according to the grounds [3].

Sumbersari Primary Healthcare is one of the Primary Healthcare in the Jember District Health Office with a high MMR. Maternal health recording and reporting are still carried out in various documents using paper-based systems such as cohorts of pregnant women, childbirth, postpartum, family planning, and MCH books. Midwives find it difficult to ensure data accuracy because paperbased systems have a limited lifespan and usually collapse due to lack of space [4]. In addition, the mother's cohort column is also small, making writing difficult to read. This condition makes it difficult for midwives to force early detection of risk factors for maternal death, so synergistic and robust information systems are needed to accelerate the decline in MMR. On the other hand, it will cause increases the danger of double input, mistakes, data loss, and a delay in the report due to a large amount of data recorded on more than one sheet. In this situation, there is no mechanism to help midwives coordinate the implementation and reporting of high-risk pregnancies [5]. Health supervisors are expected to systematically collect, analyse and interpret health-related data needed to plan, execute and assess MMR.

Health Information Technology (HIT) has the potential to be a crucial tool in addressing racial and ethnic inequalities in maternal morbidity and mortality, as well as socioeconomic and geographic inequities (MMM). HIT is critical, given that roughly $60 \%$ of maternal fatalities are avoidable. The intervention of HIT to deal with the fundamental reasons of inequality on the patient, clinician, and healthcare device stage can reduce exceptional obstetric inequality [6].

Therefore, the purpose of this study is to make the healthcare system more valuable and effective for healthcare professionals by establishing a webbased information system that simplifies the monitoring, detection, and reporting of highrisk pregnancies in Jember Regency. It was to provide a solution to make things happen. 


\section{RESEARCH METHOD}

The study was done in Sumbersari Primary Healthcare and was qualitative. The data was collected between July and September of 2021. The research population consists of midwives who utilize the information system and head of Sumbersari Primary Healthcare.

It was a research and development study to develop a web-based information system for detecting high-risk pregnancy using an education system design with a software development life cycle (SDLC) paradigm. SDLC is also a pattern for developing software systems that consist of planning, analysis, design, implementation, testing, and maintenance phases [7].

\section{RESULTS AND DISCUSSION}

\subsection{Analysis}

This stage involves analyzing system features, system demands and constraints, and developing health worker requirements. This study has already carried out the analysis through in-depth interviews with ten midwives and the Head of Sumbersari Primary Healthcare. The results showed that detecting high-risk pregnancies manually using an excel format was a lengthy procedure. They all agreed that they needed to innovate by utilizing a web-based approach.

\subsection{Design}

An outline and description of the system, as well as a storyboard, are developed. Modules, software programs, and instruments are created and determined to assess the quality of system modules [8]. The result of the analysis phase of this project was the creation of a web-based information system aimed at supporting and facilitating midwives as program implementers. This system is written on a local webserver (PHP) and can be run directly on the machine. In addition, this study created a means for assessing integrity, timeliness, accuracy, and suitability using the Likert scale (2).

\subsection{Development}

During the development phase, instructional designers and developers build and combine parts that were previously designed. Designers develop storyboards and visuals at this phase [9]. The webbased system is shown in the figure below:

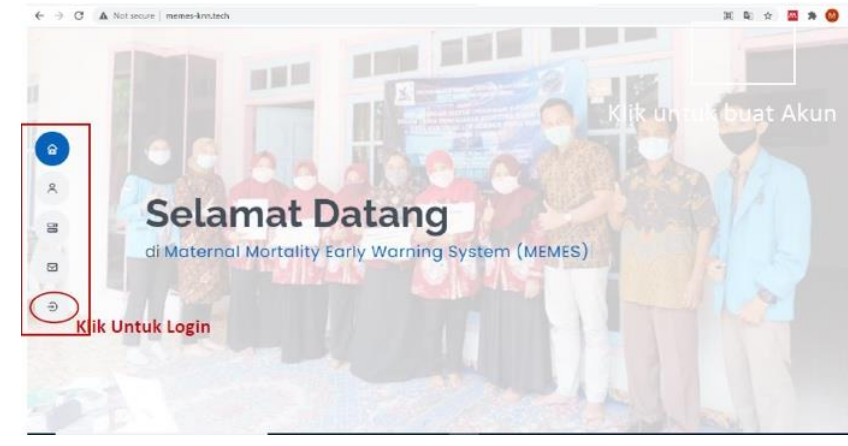

Figure 1 Homepage Design

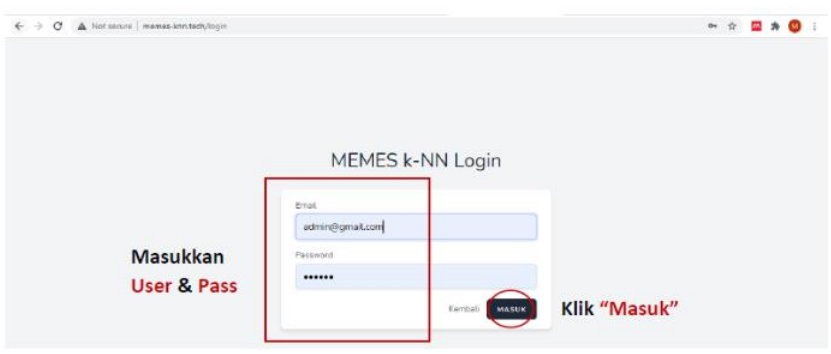

Figure 2 Log in Page

Figure 1 and 2 shows the home page of maternal health status report system-it consisting of the main menu, namely archives, blogs, and logins. The users of this system are midwives in Sumbersari Primary Healthcare, and the end-user is the Head of Sumbersari Primary Healthcare.

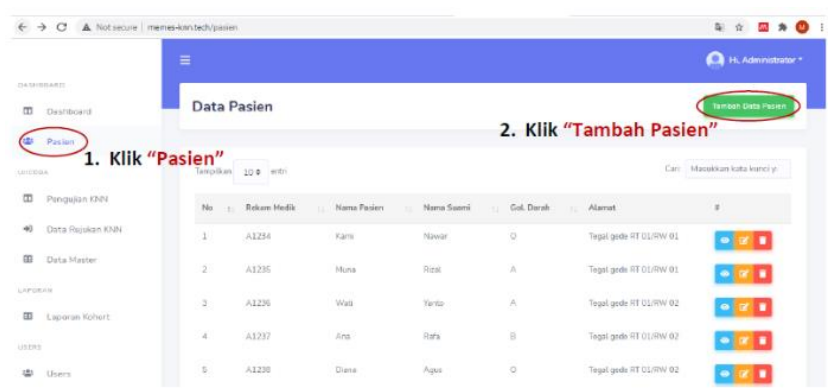

Figure 3 The Data of Pregnant Woman (1)

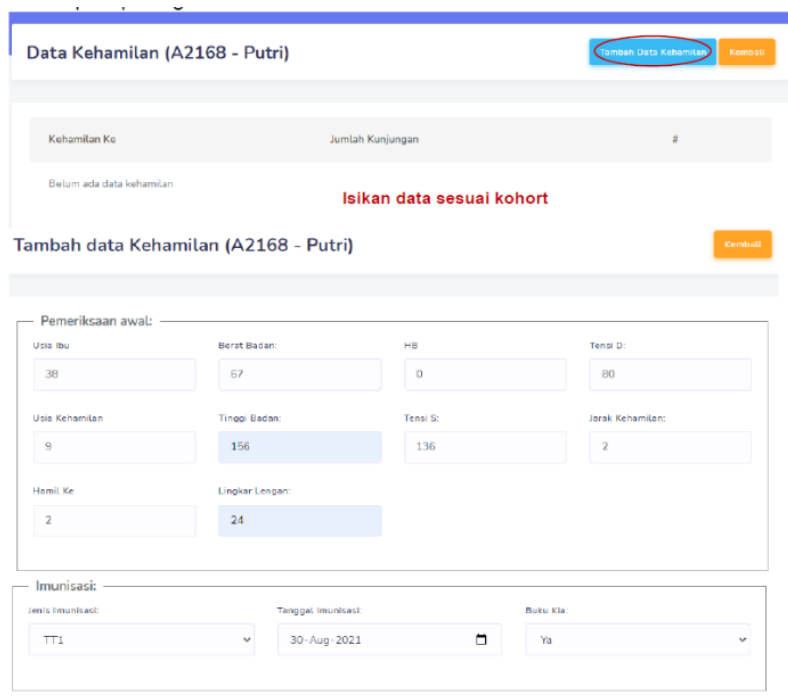




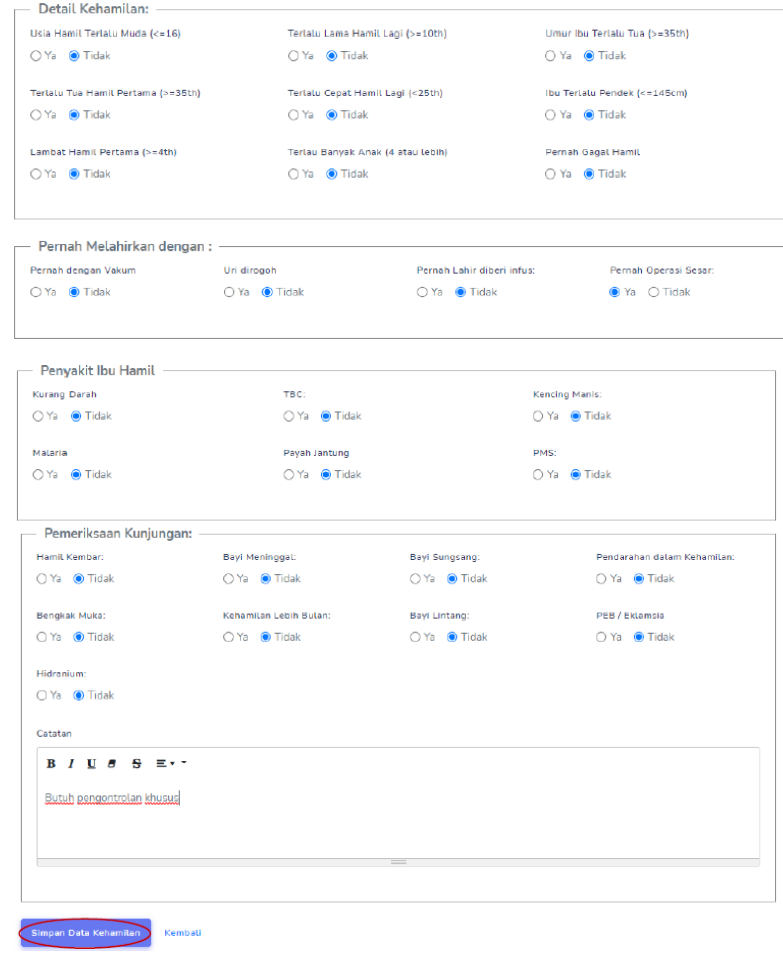

Figure 4 The Data of Pregnant Woman (2)

Figure 3 and 4 showed that the demographic data such as name, age, working status, education, address, contact, husband data, and the ownership of maternal book.

Detail Kehamilan

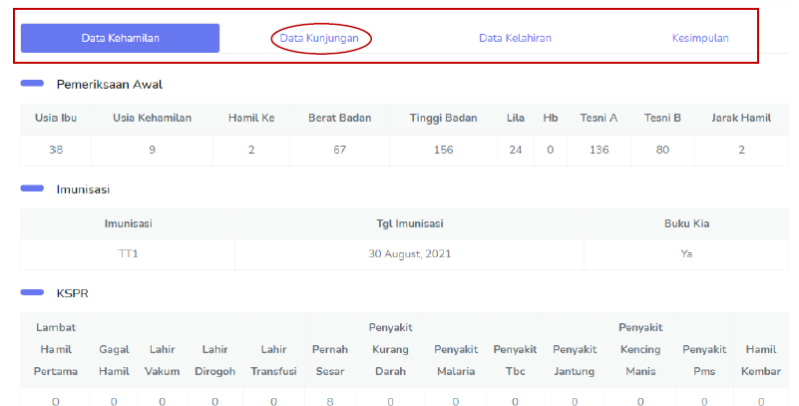

Figure 5 The Data of Pregnant Woman (3)

This section provides a history of pregnant mothers' ANC visits. It includes where the mother had the ANC, the ANC service provider, and the number of health checks from early to late pregnancy [10]. It also has a menu for entering risk factors for all kinds of pregnancy that pregnant women face. The results are a grouping of pregnancy risks based on the Poedji-Rochjati score modified by the researchers.

\subsection{Implementation}

Prototypes are tested on responders throughout the implementation phase [9]. The web-based method was deployed in this study to 18 respondents (midwives) and the Head of Sumbersari Primary Healthcare.
The next step is for the user to implement the system. Researchers conducted socialization and training on the use of the system. The input of the results of the examination of the health status of pregnant women is carried out by the Sumbersari Health Center midwife as a user.

\section{CONCLUSION}

From this, we can conclude that web-based information systems have had a significant impact on detecting high-risk pregnant women. This invention is predicted to help lower maternal death rates in Indonesia, particularly in Jember Regency. This system is very helpful for users (midwifery) to record the health status of pregnant women in Sumbersari Health Center. Therefore, this system needs to be further developed so that it can play a maximum role in reducing maternal mortality in Jember Regency.

\section{ACKNOWLEDGMENTS}

This paper, titled Design of Maternal Health Status Report System to Decrease Maternal Mortality in Jember Regency, is submitted to fulfill ICOSHIP 2021. We sincerely thank the Ministry of Education, Culture, Research, and Technology Indonesia and Politeknik Negeri Jember for funding this research and Jember District Health Office and Sumbersari Primary Healthcare so this research can be carried out well. Hopefully, this script will positively contribute to the educational development of those who want to carry out further research.

\section{REFERENCES}

[1] Timur DKPJ. Profil Kesehatan Provinsi Jawa Timur, Profil Kesehatan Provinsi Jawa Timur. 2019.

[2] Dinas Kesehatan Kabupaten Jember. Profil Kesehatan Kabupaten Jember Tahun 2016, Dinas Kesehatan Kabupaten Jember. 2017.

[3] Menteri Kesehatan RI. Peraturan Menteri Kesehatan Republik Indonesia tentang Sistem Informasi Manajemen Rumah Sakit. Jakarta; 2013.

[4] Damayanti NA, Setijanto D, Hargono A, Wulandari RD, Santi MW, Tjahjono B, et al. Integrated information system for early detection of maternal risk factors based on continuum of care approach of mother and toddler cohorts. Healthc Inform Res. 2019;25(3):153-60.

[5] Fajriya II, Supriyana S, Bahiyatun B, Widyawati MN. Developing a Web-Based Information System in Detection of High-Risk Pregnancies in Semarang, Indonesia: Addie Model. Belitung Nurs J. 2017;3(4):390-8.

[6] Jean-Francois B, Bailey Lash T, Dagher RK, Green 
Parker MC, Han SB, Lewis Johnson T. The Potential for Health Information Technology Tools to Reduce Racial Disparities in Maternal Morbidity and Mortality. J Women's Heal. 2021;30(2):274-9.

[7] Jubilee Enterprise. Mudah Membuat Aplikasi Absensi dengan Java. Elex Media Komputindo. $2015 ; 128$.

[8] Nur Kholifah L, Supriyana S, Bahiyatun B, Widyawati MN. Using Addie Model To Design Early Detection System of Child Growth and Development in the Community Health Center of Bendosari, Semarang Indonesia. Belitung Nurs J. 2017;3(3):205-12.

[9] Putri S, Hadi I, Kuntjoro T, Sumarni S. the Development of E-Partograph Module As a Learning Platform for Midwifery Students: the. 2020;3(2):148-56.

[10] Mahmood MA, Hendarto H, Laksana MAC, Damayanti HE, Suhargono MH, Pranadyan R, et al. Health system and quality of care factors contributing to maternal deaths in East Java, Indonesia. PLoS One [Internet]. 2021;16(2 February):1-13. Available from: http://dx.doi.org/10.1371/journal.pone.0247911 